\title{
MENGEMBANGKAN KECERDASAN ANAK MELALUI PENDIDIKAN USIA DINI
}

\author{
Istina Rakhmawati
}

SMP 1 Undaan Kudus

\begin{abstract}
Nowadays there are many parents who recruit children to have education until junior high school or vocational school. It is because of financial case and parents just follow the attitude of society in general. Going to school is not a requirement but merely the fulfillment of social needs. They are afraid to say miser for not sending their children, their worries will be removed from the social community for not sending their children, and there are also those who feel guilty if they do not send their children there. In short, the school is only as the fulfillment of social needs. What happened to these people? Apparently, they never send children and grandchildren since hereditary. If they go to school, it is just as a formality, so that education will have no impact on the change in mindset and behavior in everyday life. Their children already can be sure to have "poisoned" with the mindset that is not profitable, so they receive only for the school and this against the current by the word of God, which means: " $O$ ye who believe, guard yourselves and your families from a fire hell that fuel is men and stones; guardian angels of the rough, tough, who do not disobey Allah in what He commands them and always do what they're told."
\end{abstract}

Keywords: Education, Early Age, the Golden Age

\section{A. Pendahuluan}

Kehadiran anak di tengah-tengah keluarga menjadi pelengkap kebahagiaan keluarga tersebut. Anak merupakan amanah yang diberikan oleh Allah kepada siapa saja yang Dia kehendaki. Anak merupakan bagian dari kuasa dan takdir Allah Swt kepada hamba-hambanya. Dalam agama Islam, Allah memerintahkan para orang tua untuk senantiasa mendidik anak-anaknya dengan sebaik mungkin.

Mendidik anak sedari kecil adalah suatu keharusan yang perlu untuk dilakukan, agar anak tersebut dapat tumbuh menjadi orang yang beriman dan 
baik. Anak yang baik inilah yang menjadi perhiasan bagi kedua orang tuanya. Begitu pula sebaliknya, anak yang tidak didik dengan baik, maka dia dapat menjadi ancaman bagi orang tuanya sendiri. Hal itu terdapat pada Firman Allah dalam Qur'an Surat At Tagabun ayat 14 yang artinya: "Hai orang-orang yang beriman, sesungguhnya di antara istri-istrimu dan anak-anakmu ada yang menjadi musuh bagimu, maka berhati-hatilah kamu terhadap mereka; dan jika kamu memaafkan dan tidak memarahi serta mengampuni (mereka), maka sesungguhnya Allah Maha Pengampun lagi Maha Penyayang." (Depag. 2005:557)

Allah sangat mewajibkan hambanya untuk menjaga keluarganya dengan baik sesuai dengan syariat-syariat Islam. Allah akan menghukum siapa saja yang lalai dalam menjaga diri dan keluarganya. Peringatan Allah tersebut terdapat pada Qur'an Surat At Tahrim ayat 6 yang artinya: "Hai orang-orang yang beriman, peliharalah dirimu dan keluargamu dari api neraka yang bahan bakarnya adalah manusia dan batu; penjaganya malaikatmalaikat yang kasar, yang keras, yang tidak mendurhakai Allah terhadap apa yang diperintahkan-Nya kepada mereka, dan selalu mengerjakan apa yang diperintahkan." (Depag. 2005: 560)

Berdasarkan kedua ayat tersebut sudah sangat jelas bahwa Allah sangat mewajibkan orang tua untuk mendidik anak-anaknya agar anak tersebut dapat tumbuh menjadi anak yang berbakti dan berakhlak mulia. Mendidik anak sejak dini sudah menjadi keharusan bagi orang tua yang diamanahi anak oleh Allah. Saat ini para orang tua telah banyak terbantu dengan berdiri pendidikan-pendidikan yang dikhususkan untuk anak-anak pada usia dini. Pendidikan-pendidikan tersebut cukup membantu orang tua dalam memberikan ilmu pengetahuan kepada anak-anaknya. Pendidikan prasekolah dapat dilakukan melalui jalur formal maupun non formal. Jalur formal dapat ditempuh melalui sekolah Taman Kanak-kanak sedangkan jalur nonformal dapat dilakukan secara mandiri oleh masyarakat serta berbagai organisasi keagamaan. Pendidikan anak usia dini dilakukan untuk menumbuh kembangkan kemampuan anak dalam bersosialisasi, mengenali diri dan lingkungannya, serta untuk mengasah kecerdasannya. Lalu timbul suatu pertanyaan yang mendasar : Apa yang dimaksud dengan pendidikan anak usia dini? Bagaimana prinsip, landasan dan tujuan dari pendidikan anak usia dini? Apa saja komponen yang mempengaruhi keberhasilan pendidikan anak usia dini? 


\section{B. Pembahasan}

\section{Pendidikan Anak Usia Dini}

Menurut Departemen Pendidikan Nasional Indonesia, Pendidikan Anak Usia Dini atau disingkat PAUD adalah suatu upaya pembinaan yang ditujukan bagi anak sejak lahir sampai dengan usia enam tahun, yang dilakukan dengan memberi rangsangan pendidikan untuk membantu pertumbuhan dan perkembangan jasmani dan rohani agar anak memiliki kesiapan dalam memasuki pendidikan lebih lanjut.

Pendidikan Anak Usia Dini (PAUD) saat ini sedang digalakkan di berbagai tempat di wilayah Indonesia. Meskipun perkembangan PAUD saat ini belum menjadi prioritas, namun UU Sistem Pendidikan Nasional (Sisdiknas) No. 20 tahun 2003 telah mengatur mengenai PAUD sehingga sejak lima tahun terakhir telah dibentuk Direktorat PAUD yang merupakan bagian dari Pendidikan Luar Sekolah (PLS).

Pentingnya pendidikan anak usia dini telah banyak diteliti oleh para ahli. Menurut Lindsey, perkembangan jaringan otak dan periode perkembangan kritis secara signifikan terjadi pada tahun-tahun usia dini, dan perkembangan tersebut sangat ditentukan oleh lingkungan dan pengasuhan. Pentingnya PAUD juga dikemukakan oleh Feldman (2002) bahwa masa balita merupakan masa emas yang tidak akan berulang, karena merupakan masa paling penting dalam pembentukan dasar-dasar kepribadian, dan kemampuan bersosialisasi. Kenyataan ini memperkuat keyakinan bahwa pendidikan dasar bagi anak seyogyanya dimulai sedini mungkin, tidak hanya di usia pendidikan dasar 9 tahun, setelah sebagian besar kemungkinan pengembangan potensi anak mulai berkurang. (Jamal Ma'mur. 2009: 23-24)

Menurut Dr. Damanhuri Rosadi, pengembangan manusia yang utuh dimulai sejak anak dalam kandungan dan memasuki masa keemasan atau golden age pada usia 0-6 tahun. Masa keemasan ini ditandai oleh berkembangnya jumlah dan fungsi sel-sel saraf otak anak. Fungsionalisasi sel-sel saraf tersebut akan berjalan dengan optimal manakala ada upaya sinergis. Pada masa keemasan (Golden Age), terjadi transformasi yang luar biasa pada otak dan fisiknya, tetapi sekaligus masa rapuh. Oleh karena itu $\varangle$ masa keemasan ini sangat penting bagi perkembangan intelektual, emosi, dan sosial anak di masa datang dengan memperhatikan dan menghargai keunikan setiap anak. (Jamal Ma'mur. 2009: 39)

Di sinilah letak pentingnya pendidikan bagi anak usia dini. Dengan 42 memberikan pendidikan yang baik da sesuai hal tersebut dapat membuat 
anak dapat tumbuh dengan optimal, memiliki kecerdasan (intelektual, spiritual, emosional), serta dapat meningkatkan potensi-potensi yang ada dalam diri anak tersebut.

\section{Prinsip, Landasan, dan Tujuan Pendidikan Anak Usia Dini}

Terdapat beberapa prinsip yang dapat digunakan oleh sebuah lembaga pendidikan dalam melaksanakan pendidikan anak usia dini. Prinsip tersebut sangat penting untuk diperhatikan karena sangat menentukan kualitas pendidikan yang diselenggarakan. Prinsip-prinsip tersebut adalah sebagai berikut:

a. Berorientasi pada kebutuhan anak. Kegiatan pembelajaran pada anak harus senantiasa berorientasi kepada kebutuhan anak. Anak usia dini adalah anak yang sedang membutuhkan upaya-upaya pendidikan untuk mencapai optimalisasi semua aspek perkembangan, baik perkembangan fisik maupun psikis, yaitu intelektual, bahasa, motorik, dan sosioemosional.

b. Belajar melalui bermain. Bermain merupakan sarana belajar anak usia dini. Melalui bermain, anak diajak untuk bereksplorasi, menemukan, memanfaatkan, dan mengambil kesimpulan mengenai benda di sekitarnya.

c. Lingkungan yang kondusif. Lingkungan harus diciptakan sedemikian rupa sehingga menarik dan menyenangkan dengan memperhatikan keamanan serta kenyamanan yang dapat mendukung kegiatan belajar melalui bermain.

d. Menggunakan pembelajaran terpadu. Pembelajaran pada anak usia dini harus menggunakan konsep pembelajaran terpadu yang dilakukan melalui tema. Tema yang dibangun harus menarik dan dapat membangkitkan minat anak dan bersifat kontekstual. Hal ini dimaksudkan agar anak mampu mengenal berbagai konsep secara mudah dan jelas sehingga pembelajaran menjadi mudah dan bermakna bagi anak.

e. Mengembangkan berbagai kecakapan hidup. Mengembangkan keterampilan hidup dapat dilakukan dengan berbagai proses pembiasaan. Hal ini dimaksudkan agar anak belajar untuk menolong diri sendiri, mandiri, bertanggung jawab, dan memiliki disiplin diri.

f. Menggunakan berbagai media edukatif dan sumber belajar. Media dan sumber pembelajaran dapat berasal dari lingkungan alam sekitar atau bahan-bahan yang sengaja disiapkan oleh pendidik/guru. 
g. Dilaksanakan secara berahap dan berulang-ulang. Pembelajaran bagi anak usia dini hendaknya dilakukan secara bertahap, dimulai dari konsep yang sederhana dan dekat dengan anak, agar konsep dapat dikuasai dengan baik hendaknya guru menyajikan kegiatan-kegiatan yang berulang. (Jamal Ma'mur. 2009: 71-73)

Landasan yang digunakan dalam membangun pendidikan anak usia dini, yaitu:

a. Landasan Yuridis :

- Dalam amandemen UUD 1945 pasal 28B ayat 2 dinyatakan, "Setiap anak berhak atas kelangsungan hidup, tumbuh, dan berkembang serta berhak atas perlindungan dari kekerasan dan diskriminasi."

- Dalam UU no. 23 tahun 2002 pasal 9 ayat 1 tentang perlindungan anak dinyatakan, " Setiap anak berhak memperoleh pendidikan dan pengajaran dalam rangka pengembangan pribadinya dan tingkat kecerdasannya sesuai dengan minat dan bakatnya."

Dalam UU no. 20 tahun 2003 tentang sistem Pendidikan Nasional, bab 1, pasal 1, butir14, dinyatakan, " Pendidikan anak usia dini adalah suatu upaya pembinaan yang ditujukan kepada anak sejak lahir sampai usia 6 tahun yang dilakukan melalui pemberian rangsangan pendidikan untuk membantu pertumbukan dan perkembangan jasmani dan rohani agar anak memiliki kesiapan dalam memasuki pendidikan lebih lanjut. Sedankan pada pasal 28 tentang Pendidikan Anak Usia Dini dinyatakan: (1) Pendidikan anak usia dini diselenggarakan sebelum jenjang pendidikan dasar. (2) Pendidikan anak usia dini dapat diselenggarakan melalui jalur pendidikan formal, nonformal, dan/atau informal. (3) Pendidikan anak usia dini jalur pendidikan formal adalah TK, RA, atau bentuk lain yang sederajat. (4) Pendidikan anak usia dini jalur non formal adalah KB, TPA, atau bentuk lain yang sederajat. (5) Pendidikan usia dini jalur informal adalah pendidikan keluarga atau pendidikan yang diselenggarakan oleh lingkungan. (6) Ketentuan mengenai pendidikan anak usia dini sebagaimana dimaksud dalam ayat (1), ayat (2), ayat (3), ayat (4) diatur lebih lanjut dengan peraturan pemerintah (Jamal Ma'mur, 2009: 66)

\section{b. Landasan Filosofis}

Bangsa Indonesia yang menganut falsafah pancasila berkeyakinan bahwa pembentukan manusia pancasila menjadi orientasi tujuan pendidikan, yaitu menjadikan manusia Indonesia seutuhnya. Bangsa Indonesia juga sangat menghargai perbedaan dan mencintai demokrasi 
yang terkandung dalam semboyan Bineka Tunggal Ika, (berbeda tetapi tetap satu). Dari semboyan tersebut, bangsa Indonesia juga sangat menjunjung tinggi hak-hak individu sebagai makhluk Tuhan yang tidak bisa diabaikan oleh siapa pun. Anak sebagai makhluk individu sangat berhak untuk mendapatkan pendidikan yang sesuai dengan kebutuhan dan kemampuannya.

c. Landasan Keilmuan

Landasan keilmuan yang mendasari pentingnya pendidikan anak usia dini didasarkan kepada beberapa penemuan para ahli tentang tumbuh kembang anak. Pertumbuhan dan perkembangan anak tidak dapat dilepaskan dengan perkembangan struktur otak.

Teyler mengemukakan bahwa pada saat lahir, otak manusia berisi sekitar 100 miliar hingga 200 miliar sel saraf. Tiap sel saraf dapat berkembang sampai taraf tertinggi dari kapasitas manusia jika mendapat stimulasi yang sesuai dari lingkungan. Jean Piaget berpendapat,"Anak belajar melalui interaksi dengan lingkungannya. Anakseharusnya mampu melakukan percobaan dan penelitian sendiri. Guru bisa menuntun anak-anak dengan menyediakan bahan-bahan yang tepat. Tetapi, yang terpenting, agar anak dapat memahami sesuatu, ia harus membangun pengertian itu sendiri, dan menemukannya sendiri." Sementara Lev Vigosky meyakini bahwa pengalaman interaksi sosial merupakan yang penting bagi perkembangan proses berpikir anak. Aktivitas mental yang tinggi pada anak dapat terbentuk melalui interaksi dengan orang lain. Pembelajaran akan menjadi pengalaman yang bermakna bagi anak jika ia dapat melakukan sesuatu atas lingkungannya. ( Ma'mur. 2009:65)

Terdapat beberapa tujuan adanya pendidikan anak usia dini. Secara umum, tujuan pendidikan anak usia dini adalah mengembangkan potensi anak sejak dini sebagai persiapan untuk hidup agar dapat menyesuaikan diri dengan lingkungannya. Secara spesifik, pendidikan anak usia dini dibagi menjadi dua tujuan yaitu:

a. Untuk membentuk anak Indonesia yang berkualitas, yaitu anak yang tumbuh dan berkembang sesuai dengan tingkat perkembangannya sehingga memiliki kesiapan yang optimal di dalam memasuki pendidikan dasar dan dalam mengarungi kehidupan di masa dewasa.

b. Untuk membantu menyiapkan anak mencapai kesiapan belajar (akademik) di sekolah. (Ma'mur, 2009: 70) 
3. Komponen yang mempengaruhi keberhasilan pendidikan anak usia dini.

Terdapat beberapa komponen yang ikut berperan dalam menunjang keberhasilan pendidikan anak usia dini. Komponen-komponen tersebut yaitu:

a. Keluarga

Orang tua adalah model sekolah utama bagi anak, terutama ibunya. Dari ibunyalah anak merasakan kehangatan, kasih sayang, dan berbagai rangsangan. Setiap orang tua adalah wakil Tuhan di bumi ini, yang berkewajiban mendidik dan membesarkan anak-anak ciptaanNya. Apa yang diperintahkan dan diajarkan oleh setiap orang tua adalah perintah yang baik dan benar selaras dengan firman atau sabda Tuhan kepada semua umat di bumi ini.

Pada usia dini sering kali anak sudah dilibatkan dalam kegiatan sekolah yang disebut preschool atau playgroup. Bahkan, akibat gencarnya gerakan wanita karier, tidak sedikit anak-anak di bawah satu tahun sudah harus diasuh di TPA (Tempat Penitipan Anak). Hal ini dapat berdampak kurang baik bagi perkembangan anak.

Penelitian menunjukkan, anak yang tidak diasuh ibunya mempunyai keterbelakangan mental psikologis bila dibandingkan dengan anak yang diasuh oleh ibunya. Di dalam penelitiannya, Rene Spitz membandingkan perkembangan bayi yang diasuh di penitipan anak dan bayi yang lahir di penjara, namun mendapat perawatan ibunya. Rene menemukan bahwa unsur kelekatan ibu dan anak ternyata memegang peranan penting, di mana anak di penitipan anak terlihat depresi mental dan kurang kasih sayang. Selain itu, Brofenbrenner dalam penelitiannya di Amerika Serikat membuktikan, anak-anak yang pernah memasuki penelitian anak dalam kesehariannya akan bersosialisasi dengan kawan sebayanya saja sehingga mempunyai sikap lebih agresif, egosentris, dan impulsif dibandingkan anak-anak yang mendapat perawatan di rumah. Oleh karena itu, ibu wajib mendidik anak-anak di rumah pada usia dini karena memang itulah tugas seorang ibu.

Pendidikan dan pengasuhan anak yang harus dikembangkan dalam upaya mengembangkan kreativitas dan tumbuh kembang anak usia dini adalah children perspective, yakni pendidikan yang berpusat pada anak. Ini akan membuat anak sejak usia dini sudah mengenal rasa tanggung jawab, empati, dan tidak pemalu. John Bolby mengatakan, pada dasarnya praktek pengasuhan anak selalu ditandai dengan adanya attachment, yaitu interaksi yang terjadi antara ibu dan anak dalam rangka 
memenuhi kebutuhan anak. Pada usia dini, anak memang sepenuhnya akan menyadari diri dalam memuaskan kebutuhannya. Kebutuhan anak yang terpenuhi akan menjadikan rasa aman sehingga membentuk rasa percaya diri. (Igre Siswanto, Sri Lestari. 2012: 3-5)

b. Sekolah

Selain orang tua, sekolah juga ikut ambil peran dalam menunjang keberhasilan anak dalam membentuk konsep diri. Anak usia 4-6 tahun biasanya duduk di bangku sekolah TK. Oleh karena itu, para pembina/ guru harus mampu memahami konsep-konsep pendidikan anak usia dini dengan pemahaman orang tuanya di rumah. Ini penting untuk menciptakan figur orang tua sebagai guru di rumah.

Sebagaimana terdapat dalam garis-garis besar Program Kegiatan Belajar Taman Kanak-Kanak (Depdikbud, 1994) tujuan program kegiatan belajar anak TK adalah untuk membantu meletakkan dasar ke arah perkembangan sikap, pengetahuan, keterampilan, dan daya cipta yang diperlukan oleh anak didik dalam menyesuaikan diri dengan lingkungannya dan untuk pertumbuhannya serta perkembangan selanjutnya. Sedangkan ruang lingkup program kegiatan belajar anak TK meliputi: pembentukan perilaku melalui pembiasaan dalam pengembangan moral pancasila, agama, disiplin, perasaan/emosi, dan kemampuan bermasyarakat, serta pengembangan kemampuan dasar melalui kegiatan yang dipersiapkan oleh guru meliputi pengembangan kemampuan berbahasa, dayapikir, daya cipta, keterampilan, dan jasmani.

Menurut Carolyn Triyon dan J.W Lilienthal (Hildebrand, 1986: 45) tugas-tugas perkembangan masa kanak-kanak awal yang harus dijalani anak taman kanak-kanak: Berkembang menjadi pribadi yang mandiri, adalah berkembang menjadi pribadi yang bertanggung jawab untuk melayani dan memenuhi kebutuhan sendiri pada tingkat kemandirian yang sesuai dengan tingkat usia taman kanak-kanak; Belajar memberi, berbagi dan memperoleh kasih sayang, adalah kemampuan saling memberi dan berbagi kasih sayang antara anak yang satu dengan anak yang lain untuk dapat hidup bermasyarakat secara aman dan bahagia dalam lingkungan baru di sekolah; Belajar bergaul dengan anak lain, adalah belajar mengembangkan berhubungan dengan anak lain yang dapat menghasilkan dampak tanggapan positif dari anak lain dalam lingkungan sekolah yang lebih luas daripada lingkungan keluarga; Mengembangkan pengendalian diri, yakni belajar tingkah laku sesuai dengan tuntutan masyarakat; Belajar bermacam-macam peran orang 
dalam masyarakat, yaitu anak belajar bahwa di dalam masyarakat itu ada pekerjaan-pekerjaan yang dilakukan orang-orang tertentu yang menghasilkan jasa layanan pada orang lain dan hasil yang dapat memenuhi kebutuhan orang lain; Belajar untuk mengenal tubuh masingmasing, adalah mengenal panca indra yang dimiliki, anggota tubuh yang dimiliki dan kegunaannya dalam memperoleh pengetahuan dan dalam kaitan kegiatan makan, melakukan kebersihan, dan memelihara kesehatan serta kegiatan-kegiatan yang lain; Belajar untuk menguasai keterampilan motorik halus dan kasar, maksudnya anak belajar mengkoordinasi otot-otot halus untuk melakukan pekerjaan menggambar, melipat, mengguntung, membentuk, dan sebagainya. Kegiatan-kegiatan yang memerlukan koordinasi otot kasar misalnya berlari, meloncat, menendang dan sebagainya; Belajar mengenal lingkungan fisik dan mengendalikan, merupakan pengenalan terhadap ciri-ciri benda yang ada di sekitarnya, membandingkan ciri benda satu dengan yang lain, menggolong-golongkan benda itu, mengumpulkannya secara tepat, dan menyesuaikan diri dengan benda-benda tersebut; Belajar menguasai kata-kata baru untuk memahami anak/orang lain, maksudnya belajar belajar kata-kata baru dalam kaitan bendabenda yang ada di sekitarnya; Mengembangkan perasaan positif dalam berhubungan dengan lingkungan, adalah mengembangkan perasaan kasih sayang terhadap benda-benda yang ada di sekitarnya atau dengan anak-anak atau orang-orang yang ada di sekitarnya. (Mueslichatoen. 1990: 3-5)

Guru juga menjadi faktor terpenting dalam tercapainya pendidikan dengan optimal. Guru harus memiliki kompetensi kepribadian yang baik. Dalam Undang-Undang Guru dan Dosen dikemukakan bahwa kompetensi kepribadian adalah "kemampuan untuk memiliki kepribadian yang mantap, berakhlak mulia, arif dan berwibawa, serta menjadi teladan peserta didik." Kompetensi ini mencakup kemampuan pribadi yang berkenaan dengan pemahaman diri, penerimaan diri, pengarahan diri, dan perwujudan diri (Joko Wahyono. 2012: 32)

Seorang guru harus mampu menjalankan tugasnya dengan baik. Guru taman kanak-kanak dapat menempuh beberapa metode yang dapat membantunya dalam menyampaikan pendidikan kepada anak. Metodemetode tersebut yaitu metode bermain anak, metode karyawisata anak, metode bercakap-cakap anak, metode demonstrasi bagi anak, metode proyek bagi anak, metode bercerita bagi anak, dan metode pembagian 
tugas bagi anak.

c. Lingkungan masyarakat

Lingkungan masyarakat tempat tinggal anak adalah tempat anak menyerap informasi, fakta dan belajar bahasa. Lingkungan menjadi salah satu faktor yang mempengaruhi konsep diri anak. Oleh karena itu, masyarakat harus menyediakan lingkungan yang kondusif bagi perkembangan mental anak. Selain itu lingkungan harus turut mendukung terciptanya menciptakan nilai-nilai spiritual dalam diri anak dan pembiasaan-pembiasaan yang baik bagi perkembangan psikologis dan rohaninya.

d. Negara

Negara berkewajiban menyediakan fasilitas untuk menyelenggarakan pendidikan anak usia dini. Salah satunya adalah membangun sarana-sarana bermain anak yang memadai. Negara berkewajiban mengeluarkan kebijakan-kebijakan yang mendukung optimalisasi pendidikan anak usia dini, antara lain memberi penyuluhan akan pentingnya PAUD, meningkatkan kualitas para ibu dan instansi yang berkaitan dengan PAUD, memberi kesempatan kepada para wanita (kaum ibu) untuk mendidik anaknya sendiri tanpa harus dibebani tugas mencari nafkah, dan lain-lain. Negara juga harus mengontrol berbagai hal agar mendukung pelaksanaan tugas-tugas para ibu secara optimal. (Igrea Siswanto, Sri Lestari. 2012 6-7)

4. Kecerdasan Anak adalah Anugerah

Salah satu anugerah yang sangat luar biasa dari Allah adalah selalu dikaruniai kecerdasan. Anugerah tersebut diberikan dengan Cuma-Cuma bahkan kita tidak pernah berpikir bila seandainya disuruh untuk membayar mungkin kita tidak mampu untuk membayarnya. Kita sadar bahwa orang bisa berhasil dan sukses tentunya harus dibayar mahal melalui keahlian dan keterampilan skill, dimana skill selalu terkait dengan kecerdasan. Manusia dikaruniai kecerdasan intelektual dan spiritual oleh allah tidak lain agar manusia dapat menjadi wakilNya atau khalifah fil-ardl dengan demikian dapat mengelola kehidupan dengan lebih baik.

Lebih jauh lagi setiap anak yang dilahirkan di muka bumi ini sudah dibekali kecerdasan, artinya bahwa setiap anak berpotensi untuk cerdas. Berdasarkan potensi kecerdasan tersebut setiap anak manusia sesungguhnya berpotensi untuk menjadi manusia yang genius. Namun 49 
sayang sekali terkadang kapasitas otak yang dipergunakan oleh manusia pada umumnya hanya dipakai untuk hal-hal yang sederhana atau kebanyakan orang kurang percaya dengan kemampuan otak kita. Kita sering kali enggan untuk berpikir kritis, enggan untuk berpikir yang rasional dan tidak menutup kemungkinan di antara kita ingin berpikir yang instan, cepat saji dan kurang mau berpikir sebagai suatu proses keberhasilan usaha kekuatan otak kita. Pada hal jika manusia mau memakai otaknya sampai delapan persen saja, ia akan menjadi manusia genius seperti Einstein (Azzet, 2010:14).

Sebagai orang tua yang sangat mencintai anak-anak, sudah barang pasti tentu mempunyai tanggung jawab yang besar sekaligus mulia untuk bisa mengembangkannya kecerdasan pada setiap anak manusia yang sudah dianugerahkan otak oleh Allah. Jangan sampai anugerah yang luar biasa dahsyatnya ini kita biarkan begitu saja. Alangkah disayangkan bila hal ini terjadi, berarti kita menjadi hamba yang tidak bisa berterima kasih kepada-Nya karena sudah diberi anugerah, tetapi tidak dikembangkan dengan sebaik-baiknya.

Kemudian yang menjadi pertanyaan, mengapa banyak anak yang mempunyai kecerdasan yang berbeda-beda bahkan kecerdasan intelektual serta kecerdasan emosionalnya juga banyak yang berbeda. Hal ini tentu kita tidak bisa menyalahkan dengan sepihak, contohnya kita juga kurang bijaksana ketika ada anak yang tingkat kecerdasannya lebih, sementara ada juga anak yang rendah daya kecerdasan intelektualnya. Ini dikarenakan kita belum memaksimalkan potensi otak manusia sebagaimana uraian di atas. Terkadang kita malas untuk membiasakan berpikir dengan kemampuan otak kita, memang ketika kita menggunakan kemampuan otak kita untuk selalu berpikir yang rasional otak kita terasa lelah, dan kelelahan ini sudah menjadi sifat dasar manusia. Akan tetapi ketika kita tidak mau melatih otak kita untuk selalu berpikir sedikit demi sedikit, otak kita kita menjadi manja artinya malas untuk diajak berpikir, malas untuk diajak maju, malas untuk diajak berkembang dan lain sebagainya.

Disinilah perlunya setiap orang tua untuk selalu memperhatikan hal ini termasuk melatih, mengembangkan, menumbuhkan kecerdasan anak sejak usia dini. Termasuk memerhatikan tindakan yang nyata bukannya mengembangkan kecerdasan sang anak itu sendiri, melainkan justru akan menghambat kecerdasannya. Misalnya ketika mendapati anaknya mencorat-coret dinding ruang tamu, orang tua langsung marah. 
Orang tua langsung marah dengan marahan " kamu ini bagaimana? Tidak boleh mencorat-coret dinding nanti kalau ada tamu kita akan malu" dan masih banyak lagi. Pada saat orang tua membentak si anak agar tidak mencorat-coret dinding tamu lagi, sesungguhnya pada saat yang sama orang tua telah menghambat salah satu kecerdasan kreatif sang anak tersebut. Padahal tugas dan tanggung jawab orang adalah mengembangkan kecerdasan anak. Alangkah lebih bijaksananya anak tersebut dikasih tahu yang baik lalu orang tua mengarahkan untuk mencorat-coret dinding tersebut digantikan di atas lebar kertas atau sebuah buku gambar dan bila perlu dituntun dan diambilkan buku gambar tersebut sembari menasihati dan mengajari coretan tersebut beralih ke sebuah buku dan masih banyak lagi.

Dan tidak sabar ketika melakukan tindakan serupa ternyata justru menghambat kecerdasan sang anak itu sendiri. Sebenar ada tawaran solusi untuk mengatasi hal ini, misalnya kita melarang anak untuk mencorat-coret dinding tamu, akan tetapi ketika kita melarang anak terkesan tidak melarang juga terkesan tidak memarahi. Misalnya kita memuji anak tersebut dengan kalimat yang memuji anak tersebut “ wah gambarnya sangat bagus, tapi ini di ruang tamu nak? Gimana kalau ada tamu dan mendapati dinding rumah kita dikira kotor, ayo setelah ini kita lanjutkan membuat coretan di garasi saja" dan masih banyak lagi. Ternyata sang anak yang mencoret dinding ruang tamu tidak merasa tersinggung, apalagi dimarahi, tetapi justru diberikan pujian bahwa gambarnya bagus. Pada saat yang sama orang tua memberikan pengertian kepada anak kita untuk selalu menjaga agar dinding ruang tamu rumah kita harus selalu terjaga kebersihan dan nanti kalau ada tamu kita tidak malu karena dinding ruang tamu rumah kita bersih dan indah.

Dengan demikian ternyata kecerdasan bisa kita bangun dan kita kembangkan di lingkungan manapun selagi kita mau, dan kecerdasan yang kita bangun ini merupakan anugerah yang tiada ternilai harganya. Hal ini adalah merupakan tanggung jawab kita bersama setiap orang tua. Sebab di samping anugerah anak juga merupakan amanat yang diberikan Allah kepada kita. Sedang dalam amanat yang diberikan kepada kita ada tanggung jawabnya di hadapan Allah bagaimana mendidik anakanaknya. 


\section{Golden Age Anak}

Menurut Dr. Damanhuri Rosadi dalam buku "Manajemen Strategi Pendidikan Anak Usia Dini" pengembangan manusia yang utuh dimulai sejak anak dalam kandungan dan memasuki masa keemasan atau golden age pada usia kanak-kanak atau 0-6 tahun. Masa keemasan ini ditandai oleh berkembangnya jumlah dan fungsi sel-sel saraf otak anak. Fungsionalisasi sel-sel saraf tersebut akan berjalan dengan optimal manakala ada upaya sinergi.

Pada masa keemasan (golden age), terjadi transformasi yang luar biasa pada otak dan fisiknya, tetapi sekaligus juga masa rapuh. Oleh karena itu, masa keemasan ini sangat penting bagi perkembangan intelektual, emosi, dan sosial anak di masa datang dengan memperhatikan dan menghargai keunikan setiap anak. Apabila masa keemasan ini sudah terlewati, maka tidak dapat tergantikan.

Melihat tantangan ke depan yang semakin dahsyat, pendidikan anak usia dini harus segera diintensifkan dan dimaksimalkan di seluruh wilayah Indonesia. Memasuki milenium ketiga, Indonesia dihadapkan pada tantangan untuk menyiapkan masyarakat menuju era baru, yaitu globalisasi yang menyentuh semua aspek kehidupan. Dalam era global ini, seakan dunia tanpa jarak. Komunikasi dan transaksi ekonomi dari tingkat lokal hingga internasional dapat dilakukan sepanjang waktu. Demikian pula nanti ketika perdagangan bebas sudah diberlakukan, tentu persaingan dagang dan tenaga kerja bersifat multi bangsa. Pada saat itu, hanya bangsa yang unggullah yang mampu bersaing. Pendidikan mempunyai peran signifikan dan krusial dalam mengajar ketertinggalan ini.

Pendidikan merupakan modal dasar untuk menyiapkan insan yang berkualitas. Menurut undang-undang Sisdiknas, pendidikan adalah usaha sadar dan terencana untuk mewujudkan suasana belajar dan proses pembelajaran agar peserta didik secara aktif mengembangkan potensi dirinya untuk memiliki kekuatan spiritual keagamaan, pengendalian diri, kepribadian, kecerdasan, akhlak mulia, serta keterampilan yang diperlukan dirinya, masyarakat, bangsa, dan negara. Menurut UNESCO, pendidikan hendaknya di bangun dengan empat pilar, yaitu learning to know, learning to do, learning to be, dan learning to live together. Pada hakikatnya, belajar harus berlangsung sepanjang hayat. Untuk menciptakan generasi yang berkualitas, pendidikan harus dilakukan sejak usia dini.

Di sinilah urgensi pendidikan anak usia dini, yaitu pendidikan yang 52 ditujukan bagi anak sejak lahir hingga usia 6 tahun. Sejak dipublikasikannya 
hasil-hasil riset mutakhir di bidang neuroscience dan psikologi, maka adanya pendidikan usia dini merupakan keniscayaan. Pendidikan di usia dini menjadi sangat penting mengingat potensi kecerdasan dan dasar-dasar perilaku seseorang terbentuk pada rentang usia ini.

Dengan diberlakukannya UU No. 20 Tahun 2003, maka sistem pendidikan di Indonesia terdiri dari pendidikan anak usia dini, pendidikan dasar, pendidikan menengah, dan pendidikan tinggi yang keseluruhannya merupakan kesatuan yang sistematik. Pendidikan anak usia dini diselenggarakan sebelum jenjang pendidikan dasar. Pendidikan anak usia dini Pendidikan anak usia dini dapat diselenggarakan melalui jalur pendidikan formal, nonformal, dan/atau informal. Pendidikan anak usia dini pada jalur pendidikan formal berbentuk Taman Kanak-kanak (TK), Raudhatul Athfal (RA), atau bentuk lain yang sederajat. Pendidikan anak usia dini pada jalur pendidikan nonformal berbentuk Kelompok Bermain (KB), Taman Penitipan Anak (TPA), Taman Pendidikan al-Qur'an, atau bentuk lain yang sederajat. Pendidikan anak usia dini pada jalur pendidikan informal berbentuk pendidikan keluarga atau pendidikan yang diselenggarakan oleh lingkungan masyarakat. Pemberian pendidikan pada anak usia dini akui sebagai periode yang sangat penting dalam membangun sumber daya manusia dan periode ini hanya datang sekali serta tidak dapat diulang lagi, sehingga stimulasi dini salah satunya adalah pendidikan mutlak diperlakukan.

Lalu, pendidikan yang bagaimanakah yang diperlakukan? Tentu saja pendidikan yang tidak sekedar mengejar target kurikulum, atau untuk mengejar keinginan masyarakat/orang tua, seperti kemampuan anak dalam membaca, menulis, dan berhitung secara maksimal, tetapi pendidikan yang sesuai dengan pertumbuhan dan perkembangan anak.

Pendidikan bagi anak usia dini telah berkembang luas, baik di negara maju maupun di negara yang sedang berkembang. Berbagai macam program pendidikan anak usia dini ini dikembangkan oleh pemerintah, swasta maupun masyarakat. Minat mengembangkan pendidikan anak usia dini sebenarnya bersumber dari lima macam pemikiran:

Pertama, Meningkatkan tuntutan terhadap pengasuhan anak dari para ibu yang bekerja, yang berasal dari berbagai tingkatan sosial ekonomi.

Kedua, Adanya perhatian yang dikaitkan dengan produktivitas, persaingan yang bersifat internasional, permintaan tenaga kerja yang bersifat global, kesempatan kerja yang luas.

Ketiga, Pandangan bahwa pengasuhan anak sebagai sesuatu kekuatan utama guna membantu para ibu untuk meningkatkan kualitasnya, baik 53 
sebagai ibu maupun sebagai sumber daya manusia pada umumnya, sehingga dapat bersaing dalam pasar tenaga kerja.

Keempat, Adanya hasrat untuk meningkatkan kualitas anak sejak usia dini terutama bagi mereka yang orang tuanya kurang beruntung, antara lain yang kurang mampu memasukkan anak ketaman kanak-kanak.

Kelima, Program untuk anak usia dini mempunyai dampak positif yang panjang terhadap peningkatan kualitas perkembangan anak (Asmani, 2009:44). .

Pendidikan anak usia dini (PAUD) merupakan bagian integral dalam sistem pendidikan nasional yang saat ini mendapat perhatian cukup besar dari pemerintah. Konsep PAUD merupakan adopsi dari konsep Early Child Care and Aducation (ECCE) yang juga merupakan bagian dari Early Child Development (ECD). Konsep ini membahas upaya peningkatan kualitas SDM dari sektor "hulu", sejak anak usia 0 tahun bahkan sejak pra lahir hingga usia 8 tahun.

\section{Prinsip-prinsip Pendidikan Anak Usia Dini}

Sementara itu dalam mengembangkan kecerdasan anak di usia dini ada beberapa prinsip yang dapat digunakan oleh sebuah lembaga pendidikan dalam melaksanakan pendidikan anak usia dini. Adapun Prinsip-prinsip tersebut adalah sebagai berikut:

1. Berorientasi pada Kebutuhan Anak

Kegiatan pembelajaran pada anak harus senantiasa berorientasi kepada kebutuhan anak. Anak usia dini adalah anak yang sedang membutuhkan upaya-upaya pendidikan untuk mencapai optimalisasi semua aspek perkembangan, baik perkembangan fisik maupun psikis, yaitu intelektual, bahasa, motorik, dan sosio-emosional.

2. Belajar Melalui Bermain

Bermain merupakan sarana belajar anak usia dini. Melalui bermain, anak diajak untuk bereksploitasi, menemukan, memanfaatkan, dan mengambil kesimpulan mengenai benda di sekitarnya.

3. Lingkungan yang Kondusif

Lingkungan harus diciptakan sedemikian rupa sehingga menarik dan menyenangkan dengan memperhatikan keamanan serta kenyamanan yang dapat mendukung kegiatan belajar melalui bermain.

4. Menggunakan Pembelajaran Terpadu

Pembelajaran pada anak usia dini harus menggunakan konsep 
pembelajaran terpadu yang dilakukan melalui tema. Tema yang dibangun harus menarik dan dapat membangkitkan minat anak dan bersifat kontekstual. Hal ini dimaksudkan agar anak mampu mengenal berbagai konsep secara mudah dan jelas sehingga pembelajaran menjadi mudah dan bermakna bagi anak.

5. Mengembangkan Berbagai Kecakapan Hidup

Mengembangkan keterampilan hidup dapat dilakukan melalui berbagai proses pembiasaan. Hal ini dimaksudkan agar anak belajar untuk menolong diri sendiri, mandiri, bertanggung jawab, dan memiliki disiplin diri.

6. Menggunakan Berbagai Media Edukatif dan Sumber Belajar

Media dan sumber pembelajaran dapat berasal dari lingkungan alam sekitar atau bahan-bahan yang sengaja disiapkan oleh pendidik/ guru.

7. Dilaksanakan secara Bertahap dan Berulang-ulang

Pembelajaran bagi anak usia dini hendaknya dilakukan secara bertahap, dimulai dari konsep yang sederhana dan dekat dengan anak,agar konsep dapat dikuasai dengan baik hendaknya guru menyajikan kegiatan-kegiatan yang berulang.

Tujuh prinsip pendidikan anak usia dini ini harus diperhatikan, karena sangat menentukan kualitas pendidikan yang diselenggarakan. Jangan main paksa, instruksional, dan sejenisnya yang membuat kreativitas dan dinamika akal anak tidak berkembang secara eksploratif.

\section{Kesimpulan}

Kehadiran anak dalam keluarga merupakan pelengkap kebahagiaan keluarga. Anak merupakan amanah yang diberikan oleh Allah kepada siapa saja yang Allah kehendaki. Anak merupakan bagian dari kuasa dan takdir-Nya kepada hamba-hambanya. Seperti dalam agama Islam, Allah memerintahkan para orang tua untuk senantiasa mendidik anak-anaknya dengan sebaik mungkin. Mendidik anak sedari kecil adalah suatu keharusan yang perlu untuk dilakukan, agar anak tersebut dapat tumbuh menjadi orang yang beriman dan baik. Anak yang baik inilah yang menjadi perhiasan bagi kedua orang tuanya. Begitu pula sebaliknya, anak yang tidak didik dengan baik, maka dia dapat menjadi ancaman bagi orang tuanya sendiri. Mendidik anak sejak dini sudah menjadi keharusan bagi orang tua yang diamanahi anak oleh Allah. Pendidikan anak usia dini dilakukan untuk menumbuh kembangkan kemampuan anak dalam bersosialisasi, mengenali diri dan 
lingkungannya, serta untuk mengasah kecerdasannya.

Adapun komponen yang mempengaruhi keberhasilan kecerdasan pendidikan anak usia dini adalah bisa melalui pendidikan sekolah baik formal, informal maupun non formal. Selanjutnya anak di usia dini berupakan masa pengembangan manusia yang utuh dimulai sejak anak dalam kandungan dan memasuki masa keemasan atau golden age pada usia kanak-kanak, dimana masa keemasan ini ditandai oleh berkembangnya jumlah dan fungsi sel-sel saraf otak anak. Fungsionalisasi sel-sel saraf tersebut akan berjalan dengan optimal manakala ada upaya sinergi. Pada masa keemasan (golden age), terjadi transformasi yang luar biasa pada otak dan fisiknya, Oleh karena itu, masa keemasan ini sangat penting bagi perkembangan intelektual, emosi, dan sosial anak di masa datang dengan memperhatikan dan menghargai keunikan setiap anak. Apabila masa keemasan ini sudah terlewati maka tidak dapat tergantikan.

Sementara itu dalam mengembangkan kecerdasan anak di usia dini ada beberapa prinsip : Pertama, Berorientasi pada Kebutuhan Anak. Kedua, Belajar Melalui Bermain. Ketiga, Lingkungan yang Kondusif. Keempat, Menggunakan Pembelajaran Terpadu. Kelima, Mengembangkan Berbagai Kecakapan Hidup. Keenam, Menggunakan Berbagai Media Edukatif dan Sumber Belajar dan Ketujuh, Dilaksanakan secara Bertahap dan Berulangulang. Tujuh prinsip pendidikan anak usia dini ini harus diperhatikan, karena sangat menentukan kualitas pendidikan. 


\section{DAFTAR PUSTAKA}

Ahmad Muhaimin Azzet, Mengembangkan Kecerdasan Spiritual Bagi Anak, Yogyakarta, Kata Hati, 2010

Departemen Agama. Al Jumanatu 'Ali. Al Qur'an dan Terjemahnya. Bandung:JART. 2005.

Jamal Ma'mur Asmani, Manajemen Strategi Pendidikan Anak Usia Dini, Yogyakarta, DIVA Press.

Igrea Siswanto, Sri Lestari. Panduan Bagi Guru da orang Tua Pembelajaran Atraktif dan 100 Permainan Kreatif untuk PAUD. Yogyakarta: ANDI Yogyakarta. 2012

Jamal Ma'mur Asmani. Manajemen Strategis Pendidikan Anak Usia Dini. Jogjakarta: DIVA Press. 2009.

Bimbingan dan Konseling Sekolah, Yogyakarta, Diva Press, 2010

Joko Wahyono. Cara Ampuh Merebut Hati Murid. Samarinda: Erlangga. 2012. Mueslichatoen. Metode Pengajaran di Taman Kanak-Kanak. Jakarta: Pusat Perbukuan Departemen Pendidikan dan Kebudayaan dengan PT. Rineka Cipta. 1999. 